\section{Discovery of a New Fossil Anthropoid in South Africa}

In another column of this issue of NATURE (p. 486) there appears a communication from Dr. R. Broom, of the Transvaal Museum, Pretoria, in which he records the circumstances of discovery in July last of the skull of a new type of fossil anthropoid in South Africa, and goes on to give a preliminary report on the more striking and significant anatomical characters of his find, so far as these are patent at this early stage of examination. The specimen, as was almost inevitably the consequence of its discovery in the course of blasting operations, is fragmentary; but fortunately for the student of the palæontology of man and the anthropoids, those parts which have been found, especially the teeth and the forward parts of the brain cast, are among the most significant for determining the relation of the new fossil to previously known forms. Furtherand this is a matter of considerable moment--it is at once apparent that not only do these fragments belong to a new type of anthropoid, but also the teeth are those of an adult individual. Hence, as Dr. Broom points out, his find confirms the interpretation which has been placed upon Prof. Dart's Taungs skull, which is infantile, and establishes it by the side of this new and related specimen from the Sterkfontein caves, as "not closely allied to either gorilla or chimpanzee", but "on or near the line by which man has arisen". Dr. Broom, however, considers that he is justified in regarding his new form as differing specifically from Australopithecus, while it is probably later, belonging to the Upper Pleistocene. The further implication of his discovery is indicated when, referring to the resemblance in the teeth to those of Dryopithecus rhenanus, he emphasizes the fact that a South African Pleistocene form, showing "a number of typical human characters, not met with in any of the living anthropoids", stands in distinct relationship to the Pliocene fossil apes and especially to the Pliocene Dryopithecus of Europe, which some palæontologists have regarded as one of the most important links in the chain of relationship between the fossil apes of Europe, Egypt and Northern India and the earliest form of man.

\section{Science and Social Values}

Trme and time again in these columns, reference has been made to the fact that men of science as a whole have, in the past, paid little attention to the social consequences of their investigations and discoveries, with the result that science has been widely blamed for the present-day world-wide unrest. While there is still a body of opinion that scientific workers should disclaim all responsibility for the use to which their discoveries are put, there is a growing feeling that men of science should take a more active part in public affairs. Sir Josiah Stamp, in his presidential address on September 9 to the British Association, referred to this topic, and went on to suggest that biological and social investigations should be given more attention than they are at present receiving. On September 10, Prof. J. C. Philip, in his presi- dential address to Section B (Chemistry) of the Association, part of which is printed in this issue of NATure (see p. 492), roundly attacked those who find nothing in chemical science but explosives and poison gas, showing clearly the importance of the chemist in the modern State, though he found it necessary to urge upon his fellow chemists and other scientific workers the necessity of "throwing their weight into the scale against the tendencies which are dragging science and civilization down and debasing our heritage of intellectual and spiritual values".

ON the same day, September 10, President Roosevelt addressed a plenary session of the World Power Conference at Washington. According to the Washington correspondent of The Times, he said: "Your scientific and engineering genius is destroying one world - the world of relative scarcity-but has it yet undertaken to create the new world of abundance, which is potentially in your command, over natural energies? . . . Is enough attention being paid to 'human engineering' ? In making a valuation of resources the physical and mental energies of human beings must be included." He added that a higher form of accounting is required which "takes the social values, now left to mere assumption, into its calculations and measures them". This frank statement from the leader of a great modern State, coupled with the movement from within their own ranks, will embolden scientific workers in their approach to the almost unknown fields which lie before them in social research.

\section{Joy in Scientific Discovery}

DURING the past few days, a section of the lay press has been at pains to show by word and picture -apparently as a matter for comment-that scientific workers and others at the Blackpool meeting of the British Association have made use of the means of entertainment offered by that well-known resort, even as other folk do. That men of science can also feel and show emotion and pleasure in achieving success in their own special fields of work was the theme of Prof. D. F. Fraser-Harris's public lecture "Joy in Scientific Discovery" delivered at Thornton Cleveleys on September 15 in connexion with the Blackpool meeting. While it is true that scientific men must make an impersonal study of the laws of Nature, there is ample evidence from historical records of the joy they have felt on achieving their goal. Newton, it is said, was so agitated when his work on the law of gravitation approached completion that he had to beg a friend to complete his calculation. Faraday is well known to have greeted the successful conclusion of an experiment with boyish glee, and referred in writing of the life of the man of science to "the delight which the contented mind has in acquiring it [knowledge] for its own sake". Harvey said that "the pains of discovery are amply compensated by the pleasures of discovery". Malpighi was greatly stirred by his observation of the blood streaming through the capillaries. Jenner wrote joyfully to his 